\title{
Evaluation of Quality Policies on Education in Turkish Education System
}

\author{
Ramazan Atasoy ${ }^{1, *}$, Necati Cemaloğlu ${ }^{2}$ \\ ${ }^{1}$ Turkish Ministry of National Education, Ankara, Turkey \\ ${ }^{2}$ Gazi Faculty of Education, Gazi University, Ankara, Turkey
}

Copyright $(\mathrm{O} 2018$ by authors, all rights reserved. Authors agree that this article remains permanently open access under the terms of the Creative Commons Attribution License 4.0 International License

\begin{abstract}
It's aimed to evaluate the quality policies for education in Turkish National Educational System according to the opinions of the directors of departments for policies who are in charge at Ministry of National Educational and the projection of these policies on quality of education in this study. The study is designed as a qualitative research model and interview technique which is one of a technique of phenomenology model. Study group of this research which has used purposive sampling is consisted from all of the directors of educational polity departments who are in charge of General Directories within the Ministry of National Education. Data were analysed by content analysis in Nvivo10 packet programme. It's found that the themes and codes that were revealed in the research show parallelism with system approach. It's come through that there are progresses both capacities of physical and quantitative aspects as decreasing the kind of schools, lowering the classrooms sizes and meeting the schools with FATIH project according to the research. Despite of these founding it's also determined that quality problems in education are still keeping on. It's determined that there are many things to do especially performing theoretical quality policies; progressing of capacities of administration, teachers and programmes, applying administrative processes; proceeding on learning capacity of the students; providing of democratisation and participation and providing equality in opportunities. In addition, it has been determined that the lack of integrity in communication and coordination during the polity setting and implementation process negatively influences the system. It has been reached that the directors of polity departments deal with organizational change in the context of shaping and doing with legislation and regulations. It's suggested that hierarchical centralized structuring and distance that caused by high power have caused obstacle for transparency and participation; continuous changing and intervention abraded the system and reduced the quality of education.
\end{abstract}

Keywords Educational Policy, Equality of
Opportunities, Quality Components, Quality in Education, Administration

\section{Introduction}

Increasing of the quality of education is one of the priorities of the knowledge intensive society. Throughout the world policy makers for education look for the better ways to improve the quality of national education systems. The way for adapting to this rapid change and transforming paradigm [1] in information society also forces to review the quality oriented polity in education. Angus [2], Chong [3] and Clarke [4] define the quality aspect of education as one of the most fundamental key stone for 21 st century. It's also meant that to improve and grow qualified person corpus which both needed in educational systems generally and privately information economy $[5,6,7]$. This situation requires building the education systems beyond the traditional approaches and policies. Therefore, it is inevitable for the countries to make quality policies and quality approaches in education as priority objectives.

\subsection{Quality and Quality in Education}

However there are many different definitions for quality concept in literature, it's seen that there is not a common definition for it $[8,9,10,11,12]$. Fenech [13] and Wangmann [14] have stated that despite of the quality concept is one matter; it's composed from mutual effects of different factors in the system. Pittman [15] and Saarinen [10] emphasized that its need to focus on how to measure the quality instead of question what quality is. On the other hand the consensus among researchers is that education takes place at the centre of the quality [16, 6]. Karip [17] and Mortimore [18] regards the quality in education as a multidimensional dynamic process involved to reach a value judgment according which formed according to the 
perception and measurement of the person who defines the quality. According to Cafoğlu who stated the human as the most important aspect of the quality in education [19]; qualified education requires qualified directory, qualified teachers and qualified students. Adams [20]; Bergman [21]) and Cheng [22] assessed quality in education in terms of sources and inputs, process, contents, results and outputs, dignity and increased values.

The European Commission has set forth quality indicators based on data for set a standard to debates over concept of quality. European Commission has evaluated the quality indicators in education in four main titles as skills, successes and passing, follow up the education and sources and edifications [23] "Education for everyone movement" underline that qualified education is the fundamental right of individuals and governments and that institutes should improve this right and prove the democratically school environment [24]. Clarke [4] has pointed out that equality and quality are highly related with each other. Equality in opportunity of education expresses to provide same educational possibilities to every individual without performing school and program diversities. OECD quality indicators are focused on accessibility of education, intergenerational mobility, sex discrimination in education and performance of students and socioeconomic situation of students with disadvantageous and immigrant children [25].

As it could be understood from the definitions as below quality of the education is related with many factors and shown an inextricable form. It's seen that competence of teachers, capacity of syllabus, absenteeism, dropping out from schools, accessing to education in every level, equality in education, situation of the disadvantageous students; policies for training of qualified teachers and training and cultivating of school administrators; empowering educational employment relations and financing of education have come forth in the literature as the factors which influence the quality in education [26]. Especially it's emphasized that qualified teachers could make differences therefore it's necessary to reveal the potentials of teachers $[27,28]$.

\subsection{Quality of Education in Turkey}

Efforts for improving the quality of education are frequently debating issues in recent years in Turkey as it's been in the other countries. In the reports of ERG [29] and OECD [30] it's determined that the most basic aspect of the educational systems with higher performances is to provide qualified education opportunity to every individuals. It's seen that quality researches in education in Turkey are formed around of the needs of the industrial society. Preponderating and prefectural emphasize on quality concept in education was placed in educational policies of 1993 Çiller government in 1993 in the history of Turkish Republic. The effect of these policies which were focused on quality in education was on limited level due to structural and fundamental problems in the education system. When quality policies and practices in education in this period are evaluated, it is seen that the quantity and structure aspects were come to the forefront more than quality. It's adopted to convey quality of human and human capital in government polity of AKP (Justice and Development Party) which is a neo-liberal based party. When the 1st Strategical Plan and 10th Development Plan of Ministry of National Education (Ministry of National Education) and the latest two government plans are detected these have shown that framework of educational polity is focused on to educate high character and qualified individuals, opportunity to access education, based on having equal opportunity, compatible with labour market, an approach based on quality as a task. Also in the 2nd Strategical Plan of Ministry of National Education it's placed the increasing the quality of the education is mentioned. The Decree Laws and regulations which were published in recent years are commented as a reflection of the quality search in education [27]. A series of reforms have been performed in both secondary and higher education for removing the structural problems of educational system as Basic Training Program (1997) which has initiated by the support of the World Bank, Secondary Education Project (2006 - 2011), Various projects in Main Implementation Plan which were supported by UNICEF between 2001 - 2005, Project for Improvement of Vocational Training for the purpose to ensure compliance with European standards. In 2012, the law was enacted in order to increase the quality of education and participation rates, in order to increase the compulsory education year by three levels from twelve years to twelve years. In 2012, the law was enacted in order to increase the compulsory education year by three levels from twelve years to twelve years to the purpose of increasing the quality of education and participation rates [27, 29].'National Education Quality framework' which has published in this context is evaluated as an indicator to bring to the fore of the policies that focused on quality. However these positive steps were taken, Turkey has fallen behind the desired aim for providing the qualified education in every aspects in the scope of Dakar Activity Framework until 2015 [31]. According to Aydagül [32] Turkey was far behind the target which is to perform the six purpose of Education for All (EFA) in the criteria of Dakar Activity Framework. The internationally based assessment results (TIMSS, PISA, TALIS) that shed light on the appearance of the education systems reveal that the Turkish education system still retains the actual chronic quality problems [33, 26, 34]. When the results of PISA 2012 and PISA 2015 were detected, it's seen that Turkey couldn't reach to the aim for elevating five steps higher degree in OECD countries for the contexts of skills which is one of the aims of 1st Strategical Plan of Ministry of National Education. As it was stated by Cemaloğlu [35] there is not 
a significant positive improvement on quality of Education in Turkey.

According to the findings of researches which are evaluated the successes of the students internationally (TIMSS, PISA, PIAAC ve TALIS) İt's seen that skills that aimed to be gained have diversities in the aspects of regions and kinds of schools (PISA, 2003; 2006; 2009, 2012 and 2015), quality of education hasn't been reached to all over the country. On the other hand Turkey is far behind the OECD average in the aspect of literal, numeric and problem solving skills rates of students have shown level 1 and under level 1 lower performances; and rates of students which have lower performance on level 4 and level $5[29,33,34,36]$. According to the Better Life Index of OECD [37], Turkey is one of the first in the country group those have lowest value which the index value is 2,5 such as Brazil, Chile and Mexico.

These results pointed out the quality problem in Turkish education system in every level. It's also shown that the quality focused policies are inadequate to solve the quality problems in education. It's supposed that administrators who are in charged at Turkish Ministry of National Education will direct the future policies by their evaluation of the quality of education. In this context, the opinions of all heads of departments who are the responsible from the policies of Ministry of National Education which related with effectiveness and performing of them are needed to be known.

\section{The Object of the Study}

In this study, it was aimed to evaluate the quality policies in education, the variables influencing the quality of education and the reflection of these policies on the education quality in the Turkish National Education System according to the views of the directors of polity departments in the Ministry of National Education. The answers of the following questions are searched to reach this aim.

i. What are the opinions of directors of polity departments in Ministry of National Education regarding the quality policies in education and the components which have influence on quality?

ii. How is the effectiveness of quality polity in education of the Turkish National Education System according to the directors of polity departments in Ministry of National Education?

\section{Method}

This research was carried out in the qualitative research methodology, in the pattern of phenomenology by using interview technique. The purpose of designing a qualitative research is to obtain broader perspective on the subject studied [38]. Even when working with small groups, qualitative studies provide a wealth of in-depth knowledge, insight and understanding, when compared with quantitative studies $[39,40]$. Qualitative research does not analyse problems using the language of events and contexts by isolating them from the system of values that they have emerged and developed within them, but try to interpret the dominant network of relationships in their natural environment or to reveal their meaning [41]. In this research, the opinions of the senior officials of the Ministry of National Education on the quality of education of the Turkish National Education System were evaluated profoundly and in their own context. The interview texts obtained at the end of the interview were subjected to content analysis using the Nvivo 10 program and new concepts and correlations were found to help explain the collected data $[38,41]$.

\subsection{Study Group}

Study group of the research is consisted from the directors of polity departments of education in Ministry of National Education General Directorates. Directors of polity departments are the responsible persons who authorized for identification, creation and development of educational policies in the organisational structure of Turkish National Education. There are ten general directories in the organisation of Ministry of National Education. There are directors of polity departments who are affiliated to the related General Directorate. Directors of these directorates constitute the purposeful sampling of this research. In qualitative research it is not possible to give a definite number of sample sizes. The number of persons to be chosen as sampled could be determined according to the purpose of the research [39]. It could be assessed as a sufficient and powerful study group for the qualitative research therefore - all of the directors of polity departments were chosen as a study group and hence the study group have get a solid grasp on education polity of their directorate. Table 1 contains the characteristics of the heads of polity departments participating in the survey.

Table 1. Study Group

\begin{tabular}{|c|c|c|c|c|c|}
\hline \multirow{2}{*}{ Codes } & \multirow{2}{*}{ Gender } & \multicolumn{2}{|c|}{ Service Time } & \multicolumn{2}{c|}{ Interview } \\
\cline { 3 - 6 } PD1 & Male & 3 Years & $\begin{array}{c}\text { TH } \\
\text { Years }\end{array}$ & 11.06 .2015 & $\begin{array}{c}60 \\
\text { min. }\end{array}$ \\
\hline PD2 & Male & 2 Years & $\begin{array}{c}24 \\
\text { Years }\end{array}$ & 12.06 .2015 & $\begin{array}{c}64 \\
\text { min. }\end{array}$ \\
\hline PD3 & Male & 3 Years & $\begin{array}{c}30 \\
\text { Years }\end{array}$ & 18.06 .2015 & $\begin{array}{c}69 \\
\text { min. }\end{array}$ \\
\hline PD4 & Male & 3 Years & $\begin{array}{c}18 \\
\text { Years }\end{array}$ & 16.06 .2015 & $\begin{array}{c}60 \\
\text { min. }\end{array}$ \\
\hline PD5 & Male & $\begin{array}{c}3 \\
\text { Month }\end{array}$ & $\begin{array}{c}15 \\
\text { Years }\end{array}$ & 20.06 .2015 & $\begin{array}{c}75 \\
\text { min. }\end{array}$ \\
\hline PD6 & Male & 1 Years & $\begin{array}{c}12 \\
\text { Years }\end{array}$ & 23.06 .2015 & $\begin{array}{c}50 \\
\text { min. }\end{array}$ \\
\hline PD7 & Male & 2Years & $\begin{array}{c}10 \\
\text { Years }\end{array}$ & 24.06 .2015 & $\begin{array}{c}55 \\
\text { min. }\end{array}$ \\
\hline PD8 & Male & 3 Years & $\begin{array}{c}15 \\
\text { Years }\end{array}$ & 25.06 .2015 & $\begin{array}{c}60 \\
\text { min. }\end{array}$ \\
\hline
\end{tabular}


Directors of polity departments in Ministry of National Education Central Organisation were coded as "PD1, PD2, PD3, PD4, PD5, PD6, PD7, PD8", by researcher. 8 of 9 directors of polity departments officiated in Ministry of National Education were participated to the research. A maximum of two meetings were held on the same date in order to make the interviews more reliable. Interviews lasted an average of 60 minutes.

\subsection{Data Collection and Analysis}

Semi structured interview form which evolved by researcher was used as a data collection tool. The interview form was developed by scanning the literature and presented to the opinion of two experts of the field. Then the interview form was first applied to the two directors of polity departments. The final form of the interview was applied to the heads of eight polity departments.

Since the collection and interpretation of data in qualitative research is carried out by the researcher, the researchers' expectations and thoughts can be reflected in the research results. It is important to interpret the obtained data by different persons, and to compare the researcher's comments with these comments for ensuring to be unbiased in order to increase the internal validity of the research [38].

In order to ensure the internal validity of the research, the theme, sub-themes and coding were made by two field experts. The themes and codes found by both encoders have been compared and reached about $80 \%$ of the encodings overlap. The different codes are determined by common consensus and given the final form.

In the analysis of the data of the study, Nvivo 10 package program was used. Nvivo 10 program has been preferred because of the facilities that provide in the process of coding, analysing, reporting and modelling to the researcher. The data were analysed by content analysis which is one of the qualitative data analysis techniques. Content analysis consists of the steps of determining the objectives, defining the concepts, determining the analysis unit (s), locating the related data, developing a logical structure, determining coding categories, counting, interpreting and writing the results $[38,42]$. Specific words and concepts within the interview text were determined primarily in the content analysis. The meanings of these words or concepts have been analysed and inferences have been made about the message that is to be given in the text.

The coding that emerged in the research was found to be appropriate to the system approach and modelled in Nvivo 10 program as seen in figure 1 below. This model is in line with the views of Adams [20], Bergman [21] and Cheng [22] who assessed qualities in education in terms of sources and inputs, process, outcomes, and outputs and values. Also it can be said that this model is compatible with Framework of Ministry of National Education (2015), quality indicators in education of European Union, UNESCO and UNESCO [43, 44, 45, and 46]. The themes and coding that are included in the data analysis are listed below in Table 2 .

Table 2. The frequency of the themes and codes found by data analysis

\begin{tabular}{|c|c|c|c|c|}
\hline \multicolumn{3}{|c|}{ THEMES - CODES } & $n$ & $f$ \\
\hline \multirow{4}{*}{$\begin{array}{c}\text { Development } \\
\text { of Resources } \\
\text { (Inputs) }\end{array}$} & & Teacher capacity & 7 & 24 \\
\hline & & Administrator capacity & 4 & 13 \\
\hline & & Program capacity & 4 & 9 \\
\hline & & Physical environment & 6 & 20 \\
\hline \multirow{8}{*}{$\begin{array}{l}\text { Development of } \\
\text { Structure } \\
\text { (Process) }\end{array}$} & & Functioning and achievement & 5 & 9 \\
\hline & & Transformation, innovation & 8 & 28 \\
\hline & & Communication / Coord. & 6 & 26 \\
\hline & & School climate & 4 & 8 \\
\hline & \multirow{4}{*}{ Democratization } & Rules and regulations & 4 & 10 \\
\hline & & Interventions & 2 & 8 \\
\hline & & Transparency & 3 & 8 \\
\hline & & Participation & 6 & 9 \\
\hline \multirow{7}{*}{$\begin{array}{l}\text { Service Delivery } \\
\text { (Outcomes) }\end{array}$} & & Acces & 7 & 15 \\
\hline & & Attendance - absence & 3 & 3 \\
\hline & & Equality of opportunity & 8 & 21 \\
\hline & & Providing opportunities & 7 & 19 \\
\hline & \multirow{3}{*}{ Student Skills } & Personal skills & 4 & 7 \\
\hline & & Professional skills & 6 & 13 \\
\hline & & Social skills & 4 & 9 \\
\hline \multicolumn{3}{|c|}{ Monitoring And Evaluating } & 8 & 20 \\
\hline
\end{tabular}




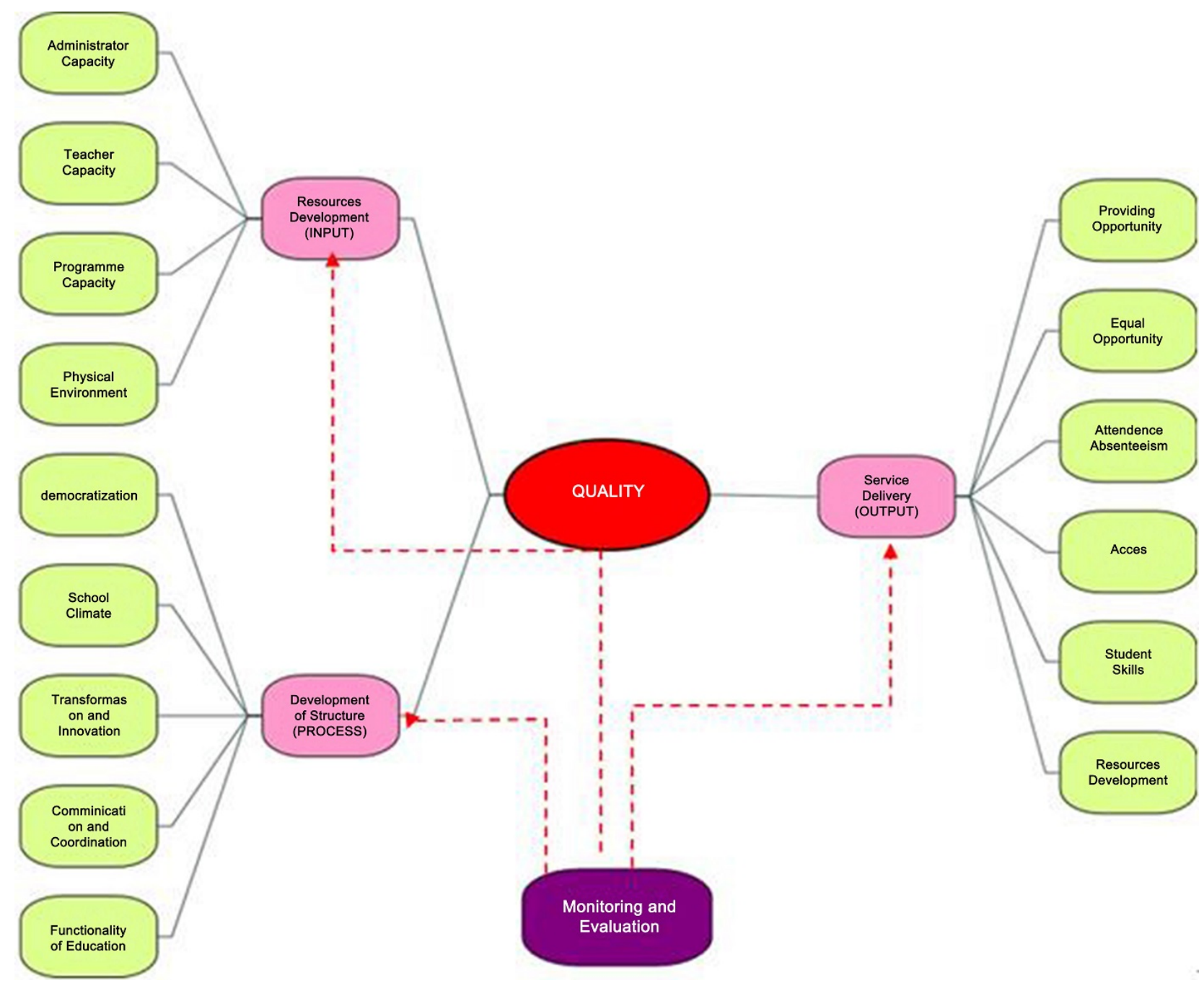

Figure 1. Quality Cycle

\section{Findings}

The opinions regarding the quality policies and quality components in education of directors of polity departments in charge of Turkish Ministry of National Education are placed in the first sub-problem of the research .Themes and codes which were revealed from the opinions of the director of polity departments have shown that quality of education is a multidimensional subject. According to the opinions of polity directors, it has been suggested that the quality of education in the Turkish National Education System should be considered within the system approach. However when the table 2 and figure 1 is examined, it can be seen that the emerged model is compatible with system approach model. In the theme of development the sources of the model (input) the coding related with directors, teachers and program capacity and data sources and physical environment $(f=73 ; n=8$ ) were mentioned.

Capacity of the teachers is the most determinant factor for the quality of education according to the opinions of director of polity departments of Ministry of National Education that is the first prominent findings $(\mathrm{f}=24 ; \mathrm{n}=7)$. A great majority of the director of polity departments think that the capacity of teachers is directly related to the quality of education. It's stated that there are problems for training of teachers in Turkish National Education System. It has been found that policies regarding capacity of teachers are mostly having quantitative approach. Some director of departments are mentioned that universities are inadequate for improving capacity of teachers as well as in - service training that offers by Ministry of National Education which are limited and content-insufficient According to some director of departments there is a need for changing on training teachers and need for a common standards to the system. A director of department, who regards the quality of education as equivalent to the capacity of the teacher, pointed out that the paradigm change is needed in the teachers. Here are the some opinions of directors of polity departments on teacher capacity sub-dimension of improving the sources theme are below.

Solving the shortcut of teacher problem as quantitate is supposed as a primary polity in countrywide [PD3]. Universities for education of teachers cannot train qualified teachers [PD2; PD5]. System for training teachers should be changed as well as in-service education [PD2; PD6]. It's not possible to increase the 
reputation of teachers by Ministry of National Education. It needs to make a change of paradigm in teachers. Teacher training policies should be scrutinised [PD3]. Quality of teachers is important. It needs to put educational materials, technological factors in one side and human factor on another side. Quality equals to teacher. Education, environment, physical capacity, all of them are knotted on the teacher [PD3; PD6].

Another coding which was come forefront in the theme of improving the sources (inputs) is the capacity of directors. When the opinions of director of polity departments are examined it's found that qualified education could be performed with 1ualified school leaders Therewithal it's stated that there are uneasiness based on the system regarding the directorate of schools and there are some disturbances on public opinion. It's expressed that there is a need for studies for training and assigning directors. Some director of policies has stated that administrative skills of school principals are insufficient; hence criteria for assigning of principals should be re-designed. In other hand it's stated that there are some subjective evaluations for choosing of school administrators sometimes. It's supposed that the new draft for new regulation for assigning directors which prepared by Ministry of National Education could fill this gap. Some opinions of director of polity departments on capacity of directors are below.

It's not possible to mention a qualified education if there are not qualified principals [PD2; PD4; PD7]. We need to create a new system that is sustained, scientific, based on teachers as a main source for general directorate of schools [PD3; PD4]. There must be steps for being principals. Directorship should be another profession. There must be a hierarchical scale to promote directorship [PD3; PD5]. There are subjective evaluations for assigning of directors of schools in every case being involved. As a ministry, we aimed to give this work to province and bring it to anyone who deserves it best. But by the times complaints and problems emerges from the field in implementation phase [PD3; PD6].

The other coding which is directly related with quality of education is capacity of the program. It's revealed that present training programs are insufficient to meet the skills for 1 st century as well as problems during implementing these skills on field. It's stated that there are some steps to update or modifying the curricula. Also the relationship between education programmes with school and teachers is broken. It's supposed that absence of standards for programs of institutes of training of teachers is the reason of that problem. Here are the opinions of some director of polity departments on program capacity are below.

We update our quality programmes in the context of skills. We see that current programmes cannot meet the demands adequately [PD1; PD2; PD4]. There is rupture between teachers and schools on curriculum. Teacher doesn't know anything about curriculum. There are not any standards in the institutes for teacher education [PD3].

Another factor which influences the quality of education is the physical structure of the education institutes. Director of polity departments of Ministry of National Education are emphasized that the studies of enhancing of the physical environment are going on but it needs to establish a standard on this issue. Directors of polity departments have stated that however there is a relationship between physical capacity and quality of education, it's not adequate to focus on only the physical aspects for education. Some directors of polity departments who have stated that there must be social habitats at schools are thought that however the physical environments have met some standards in quantitative terms; they are insufficient in qualitative terms. By applying or policies of Ministry of National Education regarding the full time schooling and policies on decreasing classroom sizes are however positive implementation, these developments are not found efficacious. Also some director of polity departments has stated that however the material sources of Turkey which are reserved for education are sufficient, the bureaucratically and political obstacles prevent the system. The opinions of director of polity department on category of physical habitat are below.

The conditions of the every regions of Turkey are not same. The measures and progresses on physical structure will be kept. Everything for material sources are available. But something is always in statement for political frame [PD1; PD2; PD4]. Our schools should be reached to standards in every aspect and should be made an attraction centre. Standards are met in quantitative terms but in qualitative terms, meeting the standards is open to question. We can't say that physical capacity is exactly adequate [PD1; PD6; PD7].

When the table 2 and figure 1 is detected it's seen that the sub dimensions of the model of development of the structure (process) are transformation and renovation, communication and coordination, school climate, functionality of the education and success. Also the coding related with rules and regulations, interventions, transparency and participation are places in sub-theme of democratisation which is the sub-theme of development theme ( $\mathrm{f}=107 ; \mathrm{n}=8$ ).

It is noteworthy that director of polity departments have mainly stated their opinions on transformation and innovation when their point of views are detected. It can be commented as a manifestation of the present situation of the quality of education and expectation on changing and modernization. Nevertheless it can be said that policies of 
Ministry of National Education regarding the changing and modernisation are mostly improving the physical edifications. Most of the directors of polity departments have stated that there is a need for a transformation and modernisation that focused on quality which w-could be integrated with world. Directors of polity departments have stated that they have noticed the efforts on simplification, facilitation and stylization for reconstruction of bureaucratically structure and sort of schools. It's specially emphasized that decreasing the sort of schools could have positive effect on quality. Just one director of polity department has stated that current quality policies are enough for quality. But it's underlined that these policies are not reflected on implementation and to the field. Some directors of polity departments has stated that there is a system changed from exam-focused practice to process focused application in the dimension of changing and renewing aspects (TEOG), and it should be assessed the transformation process of private teaching institutes in this context. In addition to this they have evaluated the weekend course which is holding at schools as a initiative to remove the habit of parents and students to private teaching institutes. Some opinions of director of polity departments on transformation and modernisation sub-dimension of improving the structure are below.

The school is not a place where education is hold into a four wall but there will be transformation for being a multi purposed institute [PD1; PD7]. We would like to compose a school which could be integrated to the world. General directorates in vocational education were gathered under a single roof for increasing the quality at schools [PD2]. Sort of schools were diminished. All of the schools have transformed to Anatolian Vocational High Schools. Sort and times of Numerical lessons were increased for qualified education. We work for empowering the technical high schools [PD2]. The most important problem of education is not to practice a simple and plain education. You need to apply the existing one [PD3]. There are studies for simplification of regulation on secondary education institution in the direction of the main policies of Prime Ministry for decreasing the bureaucracy, simplifying and facilitating of the regulations [PD4]. We passed to integration from inclusive education. We are used to changing system in a single day. There is not an exact change in perception [PD6]. It's difficult to break an accustomed culture for private teaching institute. WE can pass the problem by increasing the quality of the schools and make easier the questions for entrance test for high schools [PD8].

Another code for development of structure theme which effects quality of education is communication and coordination that are elements of process of management. According to opinions of director of polity departments of
Ministry of National Education there would be problems on functions of mechanism of communication and coordination. Some director of polity has point out existence of lack of interdisciplinary coordination and communication. However there are great experience for polity formation and polity determination, some initiatives has become just in word because of lack of coordination and administrative gaps. In the other hand some directors of polity departments emphasized that education polities directed to meet educational and business world have positive reflections on quality of vocational education. The opinions of some of the directors of polity departments on theme for improving the structure in "coordination and communication" sub-dimension are given as below:
About communication; something can be shared, but something cannot be shared [PD1]. We arrange consultation meetings with every sector to increase quality [PD2]. "The polity of the Ministry are not bas to be criticized. But there is a lack of interdisciplinary coordination [PD4; PD6].

Another variable which influences the quality of education is school atmosphere (climate) in this research (f $=8 ; n=4)$. Some directors of departments emphasized that quality of education is intertwine with the school atmosphere. It's stated that where the schools have positive school atmosphere there re higher educational quality. Some of the directors of polity departments have expressed that school atmosphere is related with mutual respect, charity and happiness; however teachers are not happy at all at the schools. One of the directors of polity department has stated that to make increased respectability of teachers is not related with economic matters; an another director of polity department expressed that there must be a paradigm shift with the matters on role, duties and responsibilities of teachers. Opinions of some director of polity departments are as below:

It's not possible to increase the respectability of teachers by Ministry of National Education. Quality means being happy. It's not possible to talk about happiness if the teacher is unhappy, if parents are unhappy, if students are unhappy [PD3; PD6]. School atmosphere will be fruitful in an environment with respect, charity and trust. Nobody wants to work in their school in the lack of these aspects. Individuals desire to be dignified. [PD7].

The most concrete of the quality of education is functionality of the education and success of educational outputs ( $\mathrm{f}=9 ; \mathrm{n}=5$ ). Some of the directors of polity departments emphasized that its need to be examined the reasons of lower performances in national and international evaluations of outputs of students. In addition to his some directors of polity departments dwelled on the research of the causes which made dissatisfied students that are the input and output of educational system from school and the 
necessity of evaluation of productivity of all educational process to reveal it. One of directors of polity departments stated that current system for evaluation of the teachers is inadequate and this situation couldn't be solved by public mentality. Here are the some opinions of directors of departments on sub-dimension of 'functionality of education and successful" as blow:

The student who came to infant school with eagerness has become dissatisfied at fifth class by us. [PD1]. The important aspect is how productive the educational and training process. You can't distinguish the one who give lecture and who doesn't give. The career is seen as Ministry of National Education. [PD3].

Another variable which influence the quality of education is the democracy factor $(\mathrm{f}=25 ; \mathrm{n}=6)$. Directors of polity departments of Ministry of National Education address the process of organizational changing more extensively in the context with legislations and regulations. According to some of the directors of polity departments, central settlement and hierarchical formation in Ministry of National Education make a negative pressure on transparency and collaborative organizational structure; constant changes and interventions eroded the system and caused reducing of the quality of education. Some of the directors of polity departments noticed the participation of all participants as parents and NGOs. Nevertheless there are some differences of the directors of polity departments in the aspects of transparency, interventions, democratization and participation. Some of the opinions of directors of polity departments on democracy sub-theme (rules and regulations, transparency, intervention and participation) as below:

There is a change on paradigm that on transition to quality from quantity [PD6]. Something can be shared something cannot. If someone tell that $4+4+4$ system wasn't shared I could ask if the uninterrupted education for 8 years shared [PD3]. Assignment instruction of school principals which we published was a model of democratic participation. $40 \%$ of them are from out of Ministry, $60 \%$ of them are from Ministry. Ministry provides school, environment, and student and Ministry of National Education resources. There should have an authority. There is an intervention caused by hierarchical structure [PD3]. Firstly, we focus on making legal and regulatory arrangements. There are efforts to reduce bureaucracy, simplify and facilitate regulations. But constant changes erode the system. Since interventions in the system are so frequent, it is not possible to fully assess the results. Generally system changes before evaluating the output of input [PD2; PD3; PD6].

As it seen in the Table 1 and figure, the sub-dimensions of the third main theme which is the service providing of the model are found as skills of the students (personal skills, vocational skills, social skills), acceptance, attendance / absenteeism, equal opportunities in education and providing opportunities $(\mathrm{f}=87 ; \mathrm{n}=8)$.

It's seen that directors of polity departments of Ministry of National Education are focused on improving of vocational and social skills of students besides of their academicals successes when their opinions are analysed (f $=29 ; \mathrm{n}=6$ ). They also stated that they directed to the approach for process instead of exam-focused approach and are working on improving self-confident of student besides of the academicals success. They also stated that they have adopted the value-focused educational policies. They stated that indicators as showing respect to others, being good citizens and to control of feelings for children could make positive influence on increasing of the quality of education and success of students. Some of the directors of polity departments also mentioned the problems for learning foreign languages that they have adopted more open policies on this issue. The director of polity departments have stated that they also work for In addition, some directors of polity departments have expressed that they have identified more explicit policies in this regard, addressing the problems of instruction observed in foreign language education. Directors of polity departments have indicated that they are also trying to implement policies towards human capital that are needed by labour markets, as well as the principle of earning the most basic level of quality education for all. Some of the opinions of directors of polity departments on coding student skills are given below.

Quality is not just a test success. We always evaluated the quality as exam-focused or result-focused. In fact besides academically achievement, bringing some criteria in the context with social skills, attending to activities, civilization and human rights are important [PD3]. We cannot give a qualified language education [PD3; PD8]. We have set policies for lack of self-confidence, self-expression and respect for others, anger control for our children [PD3; PD4]. The importance of qualified education is emerging in order to train and compete the human power that the market needs [PD1; PD2]. Our priority emphasis basic skills gain [PD3].

Another variable which influence the quality of education is accessing to education ( $\mathrm{f}=15 ; \mathrm{n}=7$ ). Directors of polity departments of Ministry of National Education have stated that main axis of policies on education are mainly focused on accessing to education [PD1; PD2]. Some of the directors of polity departments have stated that it's been reached a better level for basic education for accessing to education, but it's been lagged behind the aimed position for accessing to pre-school education. On the other hand, they stated that they aimed to increase the educational level of individuals who have 
reached with $4+4+4$ compulsory education policy [PD2; PD3; PD6]. It has also been stated that access to lifelong learning can be achieved by half of the EU average [PD6; PD6]. A director of polity department who stated that there is a relationship between access and a qualified school, has expressed that accessing to school will increase in the rate of improvement of schools' own capacities. Another director of polity department who has stated that accessing to education is one of the priority of educational policies has expressed that non-formal education opportunities are being developed for students who cannot benefit from formal education [PD8]. Another director of polity departments also mentioned that increasing the numbers of students who attend private schools is put on the agenda [PD7]. Opinions of some director of polity departments on sub - dimension of providing service theme are as below:

Prior quality policies in basic education are constituted with policies related accessing to education. WE have to handle quality after accessing to education. There are not any more difficulties on accessing to education for primary and secondary schools. But there are difficulties on policies to reach to the aimed targets for accessing to pre-school education. We make positive discrimination for school access including covering lack of teacher. In addition, distance education is provided with TRT schools and open plan schools programs. [PD1; PD3]. If the qualified schools put themselves in the foreground, the student will go there. [PD2]. In 2012, $4+4+4$ compulsory education was organized under Law No. 2687 in the context of improving quality and access to education. We attach importance to the practice of changing the negative perceptions of gender-based and disabled students to send them to the school [PD4]. It is aimed to reach adults who cannot complete formal education with open education system and distance education in order to reach to these groups [PD7]. Currently, we aim to increase the number of students who accessed to private schools from 800,000 to 3 million in 4 years [PD8].

Another variable influencing the quality of education is attendance of students to schools ( $f=3 ; n=3$ ). Some of the directors of polity departments have stated that attendance of both students and teachers is directly influence the quality of education and there are variable studies for avoiding the rate of absenteeism. Some of the opinions of directors of polity departments on attendance absenteeism sub dimension of providing services theme are as below:

Well-rounded studies perform to increase the absenteeism by keeping attendance of students of secondary schools on maximum level [PD1; PD2]. If we talk about the absenteeism and dropout from school; there is $30 \%$ of absenteeism in school [PD6]. Attendance/ absenteeism differ according to the quality of teachers [PD1].

One of the indicators which manifested in the research is equality in opportunity ( $\mathrm{f}=21 ; \mathrm{n}=8$ ). Directors of polity departments have mentioned that there are some started practices on equality of opportunity for education. Implementations for conditional transfer conveyance that some of them directed for enrolment of girls to schools, some actions for removing the differences between regions and schools, removing the impediments for get into university, some positive discriminations directed to some disadvantageous groups are some of these policies which are implemented for providing equality in opportunities [PD1; PD2; PD3; PD4; PD6; PD7]. However, they pointed out that it is not easy to completely eliminate the disparity in opportunities due to the socioeconomic level. In addition, it has been stated that there are some difficulties to assignment of experienced teachers in some regions. A group of the directors of polity departments has stated that there are problems to determine the disadvantageous students. Opinions of director of polity departments on equality opportunity sub-dimension of providing service theme are as below:

There are also policies for providing equality of opportunity in education directed to both disadvantageous students and regions. For example conditional transfer conveyance is one of them. Articles added into legislatives that informed the pre-school education is free. It's provided that pre-school classrooms put into effect at passive schools in the framework with the agreement of UNICEF. The obstacles for passing to university are removed [PD1; PD2; PD4; PD6]. Especially in the disadvantaged regions, we assign $70-80 \%$ of teachers in the first appointments. But we do not have teachers in the relevant areas [PD3]. There are concerns about the identification of disadvantaged groups [PD7].

Another variable related with quality of education is the educational opportunities which provide to students $(\mathrm{f}=19$; $\mathrm{n}=7$ ). It's seen that distributing books and tablets with FATIH project are promoting factors for increasing the quality in education according to directors of polity departments in Ministry of National Education. It's stated that increasing the social and cultural activity centres would increase the quality of education as well as academically achievements. It's also stated that policies directed to create facility and easily accessible school environments for disabled students are carried out. The opinions of director of polity departments on "providing opportunities" sub dimension of providing services theme are as below:

Increasing the amount of schools with multipurpose conference halls, sports halls, and libraries is one of 
the other works target for supporting the quality in education [PD1; PD3]. It is also seen as an incentive opportunity that provided to individuals that is distance education and to encourage schools to become centres of attraction by strengthening physical structures. In this context distributing tablets, free books and FATIH project have important roles as promoting factors [PD4; PD3; PD7]. Besides of this some directors of polity departments has stated that amount of specific schools should be increased [PD6; PD2].

All of the participants have informed their opinions for the last theme of the research that is monitoring and evaluation theme $(\mathrm{f}=20)$. Directors of polity departments of Ministry of National Education have stated their lack of monitoring and evaluating in the process. They expressed that its need to wait for the results of current policies of education. They suggested that continuous interventions to the system directly influence the results of monitoring and evaluation. Besides of this they mentioned that the results of international educational evaluations as PISA, TIMMS are indicators for status evaluation in this context. Some of the directors of polity departments are commented the results of TIMMS and PISA as positive development (!) in related with quality of Turkish National Education System.

How can you evaluate something invisible? (...) We couldn't have any opportunity to see the reconstruction of our Ministry [PD1]. PISA and TIMMs result has shown the distance we have overcome in the skills context [PD3]. The results shouldn't be counted as unsuccessful. WE have noticed the continuous evaluation in the axis of international exams PISA and TIMMS axis based on OECD countries. The system continuously changes before understanding the input and outputs [PD4]. There is a need for huge monitoring infrastructure. [PD7].

The efficiency of the quality policies in Turkish National Education System according to the opinions of directors of polity departments employed in Ministry of National Education analysed in the second sup problem of the research. The reflections of the performed policies to the quality of education are not desired level according to some of directors of polity departments. It's mentioned that since the beginning of years of 2000's however there were praiseworthy positive developments on educational policies, the problem has derived from not to put into practice these educational policies. It's stated that changing the policies before evaluation of the results has negative effect on the quality of education. In addition to this continuous political intervention to the system as caused disabling of the quality policies in education. It's found that some of the directors of polity departments have taken references the results of national and international assessment as an indicator of quality in education. In this context it's emphasized that the performance of evaluating tests as PISA or TIMMSS are lower. One of the directors of polity department has asserted the necessity of attaining the quality with holistic view. Another one has stated that political practices related with quality of education in Turkish National Education System are accepted on quantitative level. Opinions of directors of polity departments for effectiveness of Turkish National Education System to quality policies are as below.

Results of PISA and TIMMS are the indicators of the quality of our system [PD3]. The system changes immediately before we could see the results on children [PD4]. Constantly changing on policies erodes the system. It's not possible to exactly evaluation of the results for frequent interventions to the system [PD2; PD3; PD6]. The teacher training system needs to change. Programs are inadequate to develop skills. In-training system should be changed [PD2; PD3; PD6]. Teachers doesn't want to work in long term in relevant areas, therefore we can't force them to stay there [PD3]. There are difficulties for determining the disadvantageous groups [PD7].

\section{Discussion}

It's aimed to evaluate the quality policies in Turkish education system, variables which influence the quality of education and effects of these policies to quality of education according to the opinions of directors of polity departments who in charged in Ministry of National Education in this research. It's understood that quality is in interaction with many different component from the definitions and discussion on quality in education when the literature is examined $[19,13,9,10,11,12,14,55,56]$. According to the opinions of Directors of Polity Departments, it's determined that quality indicators of Turkish National Education System are multidimensional ones and having interaction with their each other, in this study. It can be said that multidimensional and intricate structure of quality of education obliged to evaluate systemically approach and to analyse with holistic view of both Turkish National Education System and quality policies in education. It's seen that themes and coding that composed from the opinions of directors of polity departments have manifested a structure appropriate to system model. This finding has shown parallelism with the arguments of Adams [20]; Bergman [21] and Cheng [22] who have evaluated the quality in education. Also it can be said that these are consonant with the quality indicators of Quality Framework of Ministry of National Education (2015), European Union and UNESCO [43, 45, 46, 56].

The opinions of directors of polity departments in charged at Ministry of National Education on quality policies in education and the components that influence the quality are evaluated in the first sub-problem of the 
research. Capacity of the teachers is one of the articles which was most widely reported issue concerning to increase the quality in education. It's stated that the most effective factor is the quality of the teachers for success of students by directors of polity departments of Ministry of National Education. This statement has shown parallelism with the results of research of Hanushek, Kain, O'Brien, and Rivkin [28]. It's emphasized supporting teachers to increase the quality of education and make difference on education in the report of $\operatorname{OECD}[26,27]$ too. On the other hand it's found that directors of polity departments have mostly criticised the teacher training policies in universities or sought the source of problems in teachers instead of developing policies directed to increase the capacity of teachers. Directors of polity departments have emphasized that policies for training and development of teachers are not the subject of public logic. In-service training activities directed to improve the quality of teachers are also inadequate.

One of the variables that influence the quality of education is the capacity of directorate. It's manifested that there is a need for sustained directorate approach in Turkish National Educational System. Besides of this it's stated that there are problems for assignment of school directorates. It's mentioned that subjective assessments and political interventions cause some systemically problems. This result has shown parallelism with the findings of Balyer and Gunduz [47] those are directorate at schools are not accepted as a profession, need for reviewing of training and assignment policies of principals and a need for modelling on prevocational training and in-service training which adopted competence principals. Korkmaz has emphasized that policy makers for education have determinant role for training and assignment of principals.

It' supposed that improving of administrative skills of principals of schools could have positive reflection on quality of education. It's also emphasized that capacity of principals of schools and teachers to response the needs for schools is on limited level [33,34]. It's mentioned that there is a need for models for principals and educational leadership those determined by common consensus of partners for achievement criteria on roles of administrators, qualification of them, assignment conditions and criteria for professional achievement in TEDMEM [48] Report of Educational Assessment which emphasized the evolving of expectation on education in 21st century. Korkmaz [49] regards that It's necessary collaboration in universities for training of qualified educational leaders.

Capacity of program is one of the key determinants for quality of education. It's mentioned that current programs are inadequate for meeting the skills of 21st century however they renovated continuously. It was also noteworthy that a bridge between teaching programs and teachers could not be established, and that the views and experiences of teachers were not addressed during the preparation of the curricula. It can be seen as manifestation of the situation which was determined in EFA (Education for All), [46] report that teachers in Turkey who met with a new syllabus in 2004 were placed only in practice phase.

Another determinant factor of qualified education is related with the physical environment of schools. There are many policies are developed for progressing of physical capacities of schools in the system of Turkish National Education. Despite of this school numbers with dual education have a higher proportion in total school numbers. It's stated that Turkey and Southern Korea have good performance for decreasing the classroom size in OECD [22] Education at Glance Interim Report. Average classroom size is stated as " 29 " in 2014 , according to the statement of Directors of Polity Departments. It seems closer to the classroom sizes of TIMMS and PISA. Average classroom size could be misleading for differences of the sizes in the regions with irregular urbanization that is a problem for quality which couldn't be overlooked. Researches have manifested that interregional population density, accumulation levels on schools and classrooms are also influence the quality of education [34, 50]. Besides of this it's stated that there is not any problem for financing of education by directors of polity departments. Despite of this it's mentioned that investigation to educational institutes in Turkey is lower than the average of OECD in Education at a Glance Report by OECD [33]. On the other hand, it should be seen as a matter to be discussed that the sources which were assigned for education couldn't reflect as well as it supposed to be on the quality of education resources can be seen as a matter to be discussed. For instance it needs to be examined the contribution of FATIH Project (Movement for Increasing the Opportunity Enhancing Technology) to quality of education by comparing its expenditure. On the other side it can be seen that there is not any coherence with the opinions of directors of polity departments for the adequacy of physical environment. While some of them stated that there was not any problem for physical environment some of them has mentioned the regional differences and sources of budget were determinant; something kept in speech in political framework, however the quantitative adequacy of the schools could be provided they could be behind of the standards for qualification aspects.

The variable that reported frequently by the directors of polity departments is transformation and renovation in education. Research for quality manifests a perpetual structure. Transformation and renovation are essential for knowledge based society. This is related with the accommodating of policies for education to changing paradigm. It's seen that directors of polity departments have shown traditional administration mentality when their opinions for transformation and renovation. Even though transformation and innovation are aimed at the future, a retrospective understanding of directors of polity 
departments' mind models can be interpreted as explaining the chaotic situations in the policy making and development process. In addition to this it's expected that reducing the General Directorate, simplifying the bureaucracy in National Education System, decreasing the type of schools, transforming regular high schools to Anatolian high schools, transforming privet courses for preparing central exams to private schools and to get by to process oriented approach from exam oriented approach can make positive effects on quality of education [27]. But for these interventions haven't done in a systemically integrity these renovation efforts have become nondurable or made the system more contentious. In addition to this for the administrative force mostly conduct the transforming and renovation aspects by back communication channels it's seen as an obstacle for accepting these renovation and transformation by personnel. Accordingly, costs for learning by experience is expensive to the system and frequently changing some aspects in huge systems as National Education System could cause not to be acceptable them by staffs [51]. It's also in the line of statements of some of directors of polity departments that the existence of interdisciplinary incoordination and lack of communication also supports this suggestion.

However the school climate is one of the determinant factors which influence the effectiveness of the school and quality of education, fewer opinions has stated in this research for this issue. However the directors of polity departments put on par with happiness and quality they have stated that employees of the institute are not satisfied. Directors of polity departments suggest that inadequacies of the teachers are the reason of poor quality in education instead of to determine policies directed to recuperative policies including the teachers.

Another finding is that stated as need for change on paradigm for success and functionality of education by an executive director that also stated the necessity to research for the reason of transformation of eagerness of students at the beginning of school to negative attitudes against to learning during the education period.

As a result efforts for democratization in Turkish National Education System influence all educational system. It can be said that qualified education requires democratically, transparent and being accountability environment. Ministry of National Education directors of polity departments deal the changing process in education in the context of legislation and regulations and formation of the structure. It can be said that quality in education requires a democratic, transparent and accountable environment. Hierarchically formation, central structuring and high force distance could cause negative effect and pressure for transparency and participation. Besides of this, I's suggested that changing and interventions those often performed on educational system erodes the system and hence decrease the quality in education. These situations have parallelism with the findings of the research of
Hofstede [52]. Turkey is one of the countries which have higher power distance [52]. Also another aspect which has put forward in the research is that some of the directors of polity departments pay attention to the participation of all of the partners as teachers, students, employee, parents and NGO's for increasing the quality of education and enhancing the school capacity. However there are discrepancies between directors of polity departments in the aspects of transparency, democratisation, participation and intervention. It doesn't seem possible to cross in a transparent, accountable, democratically governance in current administration approach which supports centralist formation in the short term. It supposed that a new administrative culture must be improved in these conditions [51, 48].

It can be said that one of the theme of this research that was providing service (outputs) allows a general assessment for the system of Turkish National Education. It's seen that there is schooling reach to $100 \%$ for basic education when we look to the Turkish Educational system. But for accessing the pre-school education it's seen that there is a situation that far behind the aimed targets. In addition to this it's stated that it's purposed to increase the accessing rates by performing $4+4+4$ execution which means to raise schooling at high schools. Despite of this it's stated that Turkey is in the second last when the rate of students completed their high school education on time was examined in OECD [33] 'Education at a Glance' report.

Equality in opportunity is an important indicator for increasing the quality in education. It's stated that it was giving priority to the policies for correcting the inequality in opportunity. Also it's emphasized that the positive discrimination policies are given weight for both disadvantageous regions and students. On the other hand it's determined that there are problems for assigning experienced teachers to disadvantageous regions as well as to retain present teachers on those regions too. It's referred in the Report of OECD report dated on 2007 stated that the differences between both schools and regions influence the learning opportunities of students. It's also mentioned that the allotment policies of financial sources should be review in the aforesaid report. However policies directed to schooling of girl children which have brought to successful conclusion, removing the inequality for admission to universities and conditional transfer conveyance implementations are evaluated as positive aspects. It's also stated in the Education Policy Outlook Highlights: Turkey Report [27] for the equality in opportunity that academically success of students who have lower socio-economic status is lower too and academically choose for choosing ad classification of students which is a policy implemented on systemic level also prevents the equality. Turkey is on the 66th rank in 132 country for accessing the basic knowledge component, on the 79th rank for accessing further education and knowledge and communication in 132 country according to social progress 
index SPI [53] which reveal integrated picture for social progression level of the countries In other hand it's reported that on the 77th rank on opportunities component and 119th rank for tolerance and inclusiveness. The main results of this index could be supposed as indicator for Turkish National Education which is in search of accessing the exact knowledge, building up a society with tolerance and in peace, pervading of further education and quality in education.

A qualified education should provide different opportunities as well as provide equality in opportunity for all of the students. In this context directors of polity departments have stated that its given weight to the policies for making schools as attraction centres. Besides of this it can be said that they give priority to some promoting factors to give possibility to enhance the personal, social and vocational skills of students and policies which provide enhancing their social lives.

The last variable that related with quality of education in Turkish National Education System is found as monitoring and evaluation. According to the opinions of directors of polity departments, there is a need for an effective monitoring and evaluating system. In addition to this changing on the system before observing the results of the implemented policies and interventions to the system continuously are seen as a greatest obstacle for an effective monitoring.

Focusing on national and international successes of students, explaining the quality of education by the lower performance on student's outputs and commenting with assessments based on data could be more rational for evaluation of effectiveness of the quality policies in education. Since the years of 2000's, it has been thought that the results of the Programme of International Student Achievement Assessment (PISA) and the Trends in International Mathematics and Science Study (TIMSS) clearly show the direction of the effectiveness of quality policies in education in the Turkish National Education System. In other saying performance of students of Turkey in international comparisons is under the average of OECD and continuous to remain on the places.

According to the Bette life Index provided by OECD, turkey is one of the country which obtain the lower value in education aspect with Mexico, Chile and Portugal [54, 37]. Concerning the national and international evaluation performance of the Turkish National Education System, it is necessary to emphasize social and professional skills beyond exam-oriented and academic achievement practices in order to improve the quality of education. In particular, it can be said that policy makers should be more proactive in training policies in order to provide learning environments that contribute to the personal and social development of students, and to develop policies to educate individuals who are well qualified, well-qualified foreign language learners and the skills needed by the market / society.
It has also been found that the quality policies revealed are mostly related to the physical capacity and the quantity dimension of education. It can be argued that it makes it necessary to emphasize the quality dimension in education more than quantity in quality policies for education. Another consequence of this research is that to obtain quality in education it needs to take a holistic view of all parts of the system (all quality components).

As a result, it can be said that there are positive progressions for determining the conceptual framework of the quality of education if we evaluate the quality policies of Turkish National Education System with systemically approach and holistic view. Nevertheless, the sustainability of the decisions taken at the desk in the policy setting and implementation process which are disconnected from the field seems difficult to maintain. It's thought that there is a long way to go in the reflection of the theoretical quality frame to practice; developing of capacity of principal, teacher and programme; ensuring communication and coordination; in the implementation of administrative processes; democratization and sharing of participation and the development of student learning which the result of quality education is.

\section{REFERENCES}

[1] Drucker, F., P. (1993). The Practice of management. New York: Harper Business.

[2] Angus, L. (2004). Globalization and educational change: Bringing about the reshaping and renorming of practice. Journal of education policy, 19(1), 23-41.

[3] Chong, S. (2012). The Hong Kong policy of quality education for all: A multi-level analysis of its impacts on newly arrived children. International Journal of Inclusive Education, 16(3), 235-247.

[4] Clarke, M. (2014). The sublime objects of education policy: quality, equity and ideology. Discourse: Studies in the Cultural Politics of Education, 35(4), 584-598.

[5] OECD (2012a) Equity and Quality in Education: Supporting Disadvantaged Students and Schools.

[6] O'Sullivan, M. (2006). Lesson observation and quality in primary education as contextual teaching and learning processes. International Journal of Educational Development, 26(3), 246-260.

[7] Özdemir, S. M. (2011). Toplumsal değişme ve küreselleşme bakımından eğitim ve eğitim programları: Kavramsal bir çözümleme. Ahi Evran Üniversitesi Eğitim Fakültesi Dergisi, 12(1), 85-110.

[8] Balc1, A. (2005). Toplam kalite yönetimi. Y. Özden (Ed.), Eğitim ve okul yöneticiliği el kitabı içinde, Ankara: Pegem.

[9] Fairweather, J. S. \& Brown, D. F. (1991). Dimensions of academic program quality. Review of Higher Education, $14(2), 155-176$. 
[10] Saarinen, T. (2010). What I talk about when I talk about quality. Quality in Higher Education, 16(1), 55-57.

[11] Sayed, Y., \& Ahmed, R. (2011). Education quality in post - apartheid South African policy: Balancing equity, diversity, rights and participation. Comparative Education, 47(1), 103-118.

[12] Tawil, S., Akkari, A., \& Macedo, B. (2012). Au-delà du labyrinthe conceptuel: La notion de qualité en éducation. Recherche et Prospective en Education UNESCO. Contributions thématiques (2), 1-17.

[13] Fenech, M. (2011). An analysis of the conceptualization of "quality" in early childhood education and care empirical research: Promoting "blind spots" as foci for future research. Contemporary Issues in Early Childhood, 12(2), 102-117.

[14] Wangmann, J. (1995). Towards integration and quality assurance in children's services: Australian Institute of Family Studies.

[15] Pitman, T (2014) Reinterpreting higher education quality in response to policies of mass education: The Australian experience, Quality in Higher Education, 20(3), 348-363.

[16] Barrett, A., Ali, S., Clegg, J., Hinostroza, J. E., Lowe, J., Nikel, J., .... Tikly, L. (2007). Initiatives to improve the quality of teaching and learning: A review of recent literature. Report for recent literature. England: Edqual.

[17] Karip, E. (2007). İlköğretimde kalite: Avrupa Birliği kalite göstergeleri çerçevesinde kalitenin değerlendirilmesi. Türkiye'de okul öncesi eğitim ve ilköğretim sistemi temel sorunlar ve çözüm önerileri, 211-267.

[18] Mortimore, P. (1990). Measuring educational quality. British Journal of Educational Studies, 39(1), 69-82.

[19] Cafoğlu, Z. (1996). Eğitimde toplam kalite yönetimi. İstanbul: Serçe.

[20] Adams, D. (1999). Eğitimde kalitenin tanımlanması. (Çev. Necati Cemaloğlu) Kuram ve Uygulamada Eğitim Yönetimi, 4(2), 233-248.

[21] Bergman, H. (1996). Quality of education and the demand for education: Evidence from developing countries. International Review of Education, 46 (6), 581-604.

[22] Cheng, Y. C. (1997). A framework of indicators of education quality in Hong Kong primary schools: Development and application. Paper presented at the Asia-Pacific Economic Cooperation Education Forum on School-Based Indicators of Effectiveness.

[23] Gültekin, M. \& Şengül, S. A. (2006). The Condition of Turkish Education System from the Aspect of European Union's Area and Indicators Determining the Quality in Education. Anadolu Üniversitesi Sosyal Bilimler Dergisi, 6(2), 15-32.

[24] Mundy, K. (2006). Education for all and the new development compact: Springer.

[25] OECD (2015), Education at a Glance 2015: OECD Indicators, OECD Publishing. http://dx.doi.org/10.1787/eag-2015-en

[26] OECD (2013e), Education at a Glance 2013: OECD Indicators [OECD (2013), Bir bakışta eğitim 2013: OECD göstergeleri], Paris: OECD,

http://dx.doi.org/10.1787/eag-2013-en.

[27] OECD (2013d). Eğitim Politikasi Genel Görünümü, (www.oecd.org/edu/policyoutlook.htm)

[28] Hanushek, E. A., Kain, J. F., O'Brien, D. M., \& Rivkin, S. G. (2005). The market for teacher quality. (No. w11154).National Bureau of Economic Research.

[29] ERG (2013). Eğitim izleme raporu. Sakarya.

[30] OECD (2013b). PISA 2012 Results: Excellence through equity: Giving every student the chance to succeed (Volume II); Paris: OECD.

[31] UNESCO (2000). The Dakar framework for action: Education for All - Meeting our Collective Commitments. World Education Forum, Dakar: UNESCO.

[32] Aydagül, B. (2008). No shared vision for achieving Education for All: Turkey at risk. Prospects, 38(3), 401-407.

[33] OECD (2012b). Education at a Glance 2012: Paris: OECD. http://dx.doi.org/10.1787/eag higlights-2012-en

[34] OECD (2013c). PISA 2012 Results: What students know and can do: Student performance in mathematics, reading and science (Volume I); Paris: OECD.

[35] Cemaloğlu, N. (2011). PISA sonuçları ve MEB müfredatı. Türk Yurdu, 31(2), 4-6.

[36] OECD (2013a). How's Life? 2013: Measuring well-being. Paris: OECD.

[37] OECD (2013f), Better life index: Country reports, OECD, pp. 3-108. http://www.oecd.org/newsroom

[38] Buyukozturk, S., Kilic Cakmak, E., Akgun, O., Karadeniz, S. \& Demirel, F. (2012). Bilimsel arastirma yontemleri. Ankara: Pegem A.

[39] Patton, M. Q. (2014). Nitel araştırma ve değerlendirme yöntemleri. (Çev. M. B. ve S. B. Demir). Ankara: Pegem.

[40] Johnson, B., \& Christensen, L. (2012). Educational research: Quantitative, qualitative and mixed approaches. California: Sage.

[41] Neuman, W. L. (2012). Toplumsal Araştırma Yöntemleri: Nicel ve Nitel Yaklaşımlar. İstanbul: Yayın Odası.

[42] Watling, R., \& James, V. (2012). The analysis of qualitative data. Research methods in educational leadership and management,(3), 381-396.

[43] European Commission, (2000). European report on the quality of school education: Sixteen quality indicators. A report based on the work of the Working Committee on Quality Indicators. ec.europa.eu/education/policies/educ.

[44] UNESCO, (2004) EFA Global monitoring report 2005: The quality imperative. Paris: UNESCO.

[45] UNESCO (2005). Rapport mondial de suivi sur l'EPT 2005. Éducation pour tous: l'exigence de qualité. Paris.

[46] UNESCO-2015. Education for All 2000-2015: achievements and challenges, EFA Global Monitoring Report. 
[47] Balyer, A., \& Gündüz, Y. (2011). Değișik ülkelerde okul müdürlerinin yetiştirilmesi: Türk eğitim sistemi için bir model önerisi. Kuramsal Eğitimbilim Dergisi, 4(2), 182-197.

[48] TEDMEM (2014). 2014 Eğitim değerlendirme raporu. Ankara: İşkur Matbaacılık.

[49] Korkmaz, M. (2005). Okul yöneticilerinin yetiștirilmesi: Sorunlar, çözümler ve öneriler. Gazi Eğitim Fakültesi Dergisi, 25(3), 237-252.

[50] Öğülmüş, S. \& Özdemir, S. (1995). Sınıf ve okul büyüklüğünün öğrenciler üzerindeki etkisi. Kuram ve Uygulamada Eğitim Yönetimi, 1(2), 261-273.

[51] Bursalığlu, Z. (2000). Eğitimde yönetimi anlamak, sistemi çözümlemek. Ankara: Pegem.
[52] Hofstede, G. (1980). Culture's consequences: international differences in work-related values. Newbury Park: Sage.

[53] SİE (2014) Social progress index 2014, social progress imperative. Washington: D.C.

[54] Akar, S. (2014). Türkiye'de daha iyi yaşam endeksi: OECD ülkeleri ile karşılaştırma. Journal of Life Economics, 1(1),1-11. Doi: 10.15637/jlecon.201416987.

[55] Tikly, L., \& Barrett, A. M. (2011). Social justice, capabilities and the quality of education in low-income countries. International Journal of Educational Development, 31(1), 3-14.

[56] UNICEF (2000). Defining quality in education. Intervention faite lors de la réunion du Groupe de travail international sur l'éducation, Floren 